Jusmal llmial

PEUR AA DE

Vol. 5, No. 2, May 2017

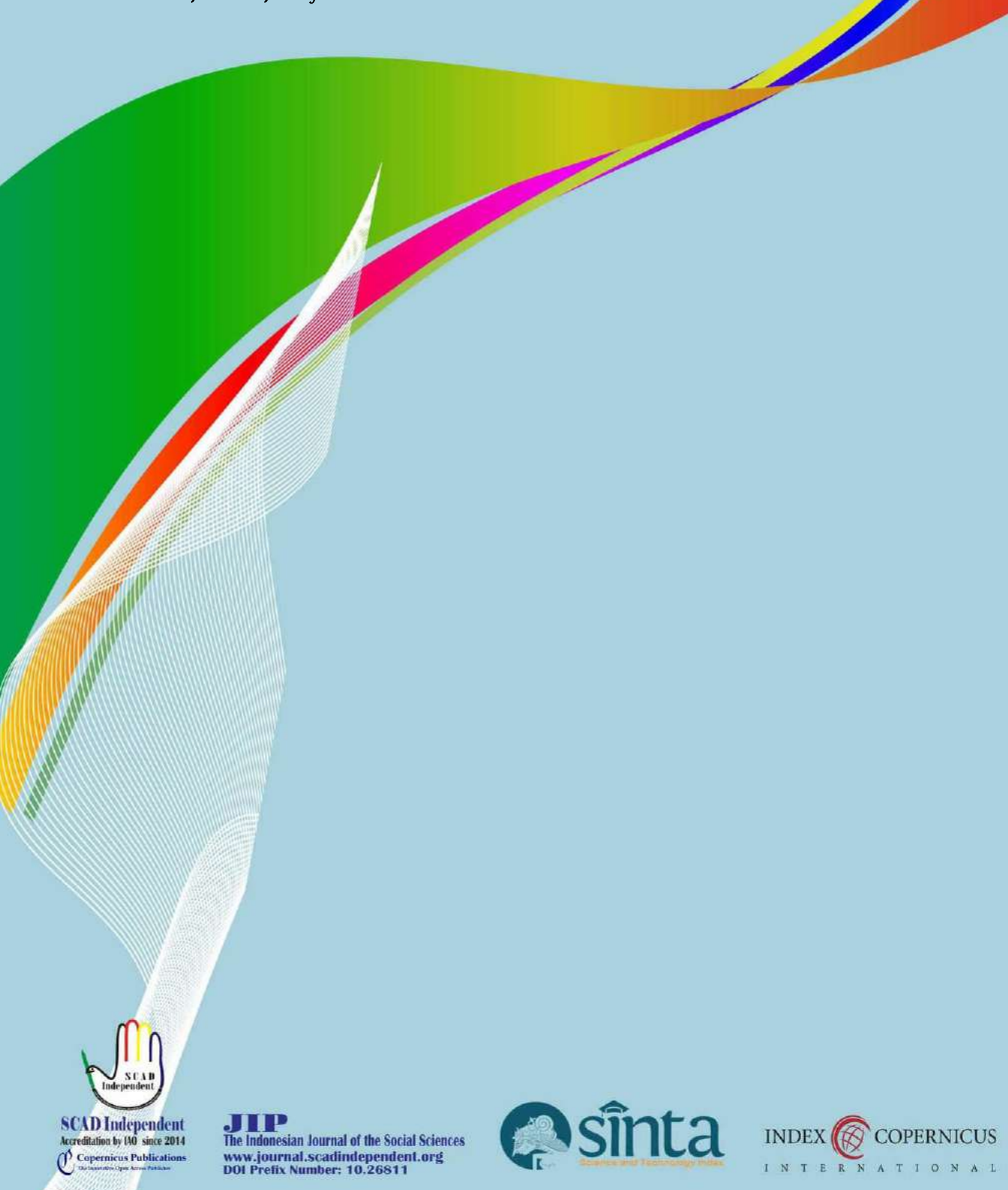




\title{
DIPLOMATIC RELATIONS BETWEEN INDONESIA-AUSTRALIA SINCE WHITLAM, FRASER, UNTIL HAWKE ERA IN AN ATTEMPT TO ESTABLISH POLITICAL STABILITY IN SOUTHEAST ASIA (A Historical Perspective)
}

\author{
Anzar Abdullah \\ Universitas Pejuang Republik Indonesia, Indonesia \\ Contibutor Email: anzarabdullah91@yahoo.co.id.
}

Received: Feb 15, 2017

Accepted: April 21, 2017

Published: May 27, 2017

Article Url: http://journal.scadindependent.org/index.php/jipeuradeun/article/view/135

\begin{abstract}
Talking about foreign policy relations of a country, it cannot be explained without adapting to the changes that occur in the growing environment or situation of both countries. Adjustments to the environment and the situation, especially the foreign policy are done in order to maintain the physical, economic, politic and social culture of the country in the midst of the real conditions of the situation occurred, like the history of bilateral relations between Indonesia and Australia). This is a study of the history of Australian foreign policy towards Indonesia since Whitlam government in 1972 until Hawke. The goal of the study is to explain how the foreign policy of the Australian Prime Ministers during their reigns. Although in reality in the course of its history, Australian and Indonesian diplomatic relations were full of intrigues, turmoil and conflicts, but it did not severe the relation of the two nations. Eventually, the conclusion of this study explicitly states that Australia and Indonesia still need each other in an attempt to establish political stability, economic and security in Southeast Asia and the Pacific peacefully.
\end{abstract}

Keywords: Indonesia-Australia, Diplomatic Relations, Political Stability, Southeast Asia 


\section{A. Introduction}

Australia-Indonesia relations refers to the foreign relations between Australia and Indonesia, which began as early as 1640 with contact between Indigenous Australians and Makassar straphangers from southwest Sulawesi, and formalized with Australia's full recognition of the Republic of Indonesia in 1949.

When Indonesia gained its independence on August 17, 1945 from Dutch colonial rule, Australia did not immediately recognize the independence of Indonesia. This is due to, their doubts about the ability of the nationalists in overcoming communism in Indonesia, as the main factor that characterizes the polemic in Canberra in its efforts to recognize the independence of Indonesia. Both the ruling Labor Party and the Liberal Party which was then in opposition, have the same consideration. Nightmares that the departure of Dutch colonial rule of the Indonesian archipelago, will lead to the threat of North- Hordes from Asia and the Yellow Peril reappear (Rohmawan, 2010: 2).

But amid such doubt, the Labor Party which basically has the confidence of anti-colonialism is more sympathetic to the Republic of Indonesia. Chipley, Prime Minister of the Australian Labor Party emerged with the conviction that the nationalist forces in Indonesia will eventually rise to a major force as the controlling state and a bulwark against communism. In addition, the Chancellor believes anyway, sooner or later the Dutch had to leave from Indonesia. Therefore, he believes that it is contrary to the interests of Australia, when Canberra maintains support at Den Haag. Apparently, the relationship between Canberra and Jakarta more intimate with the chosen Justice Kirby of Australia, to represent Indonesia in the Three-State Commission (KTN) in 1947 (Rohmawan, 2010: 2).

While the Liberal Party defeated the Labor Party in the General Election of 1949, still influenced by the paradigm doubted the ability of the Republic of Indonesia to prevent communist influence. In addition, a support for the Indonesian nationalist groups is a bad precedent for other colonial powers are still entrenched in Southeast Asia, such as the British in Malaya and the French in Indochina (Watt, 1968: 250-251). However, with the departure of the Dutch from Indonesia, Menzies Liberal Party faced with the situation that Australia should recognize the newborn of Republic of Indonesia. After the transfer of power 
from the Netherlands to Indonesia on December 27, 1949, Australia sent its Foreign Minister Spender to Indonesia to strengthen the deeper relations between the two countries. (Adil, 1977: 24).

Australian attitudes that tend to be in favor of the Netherlands were driven by the turmoil of social political and economic situation in Indonesia during the decade of the fifties. Besides the increasing influence of the Communist Party of Indonesia, this led to concerns Australia. Australia's effort to help the Dutch in West Irian is characterized by involving the United States and Pact ANZUS (Australia, New Zealand, and the United States) into the arena of conflict in West Irian. This effort was doomed to failure, because the United States for the sake of its global strategic interests, do not want to see Indonesia fell into the arms of the Soviet Union (Weinstein, 1976: 73-74, \& 111; Embassy of Australia, 1973: 5). Some Prime Minister of Australia after Manses coming from the Liberal-Country Party coalition, like Whitlam, Fraser, until Hawke and apparently had no difficulty in establishing good relations with Jakarta. Jakarta is inward looking and low profile under Suharto, may temporarily make Australia sleep soundly.

\section{B. Method}

In this paper, the use of historical research through a literature review, either in the form of books, scientific journals, published by the Embassy of Foreign Affairs, and magazines that discuss diplomatic relations between Indonesia and Australia. As a historical study, in describing its findings, the researchers conducted four main steps, namely: heuristic, by collecting a variety of published sources, such as books, scientific journals, archives and various magazines, newspapers and articles related to the focus of research. Second source is criticism by way of verification of the data or selecting historical data or information that has been collected through internal and external criticism. Third, do the interpretation, by way of interpreting historical facts obtained to get the continuity and interconnectedness between historical facts, thus forming a complete chain of events. Fourth is the stage of historiography. In this historiography, the authors conducted a compilation of historical facts in the form of scientific papers ready to be served as an account of the historical facts that have been prepared. 


\section{Research Finding}

From the analysis of the literature, it is found the historical fact that the Indonesia-Australia diplomatic relationship has lasted a long time, since the struggle for Indonesian independence. When the Labor Party had the attitude of anti-colonialism to show sympathy for the Republic of Indonesia. Australian Prime Minister at that time, which came from the Labor Party, Ben Chifley believes that the Indonesian nationalists will be a major force as the controlling State and the bulwark against communism. In addition, the Chancellor revealed that the Netherlands as a colonial must immediately withdraw from Indonesia. Therefore there is no reason for Australia to provide support to the Dutch top occupation in Indonesia. This fact is more apparent when the relationship between Australia and Indonesia more intimate when Indonesia chose Justice Richard Kirby of Australia to represent Indonesia in the Three-State Commission (KTN) in 1947 (Rohmawan, 2010: 2).

Likewise in the course of its history, Indonesia-Australia government era of era Whitlam, Fraser until Hawke experienced a relatively good relationship, although the relationship was also often experience ups and downs in the political dynamics. But in the relationship, often also heats up political tension due to the political situation the region vulnerable to the issue of East Timor issue (Azwar, 1997). This happened throughout the 1980s. Although the Australian government trying to maintain good relations with Indonesia, but sometimes the Australian press and opposition groups do not want the issue of East Timor stopped. Australia seems to meet press interest and consistent with the aspirations of a group of East Timorese living in Australia, who oppose the integration of East Timor into the territory of the Republic of Indonesia. They use the press to campaign against integration Australia-East Timor undertaken by the Republic of Indonesia through military invasion (Hamid, 1999; Robinson, 1986).

Incessant criticism of this group, following the Australian press, causes the negative perception of the Indonesian government in Jakarta. The attitude of the Australian government in Canberra, which appears to forego the Australian press criticism against Indonesia on East Timor integration, seen as an unfriendly gesture, as well as supporting the anti-Indonesia. As a result, 
relations between the two countries worsened between 1980 and 1983. The proof, marked delay visits of high officials of both countries, which resulted in the Timor Gap talks stalled (Toohey, 1986; Adil, 1977). Relations between the two countries and then improve again, after Australia provide support to Indonesia in the vote to remove the issue of East Timor on the agenda of the UN General Assembly in October 1983.

Moreover, when a crisis caused by the newspapers the Sydney Morning Herald, 10 April 1986 eased, diplomatic relations the two countries are also gradually improved. It is marked by the signing of a cooperation agreement and regulatory mining zone in the Timor Gap. This is the beginning of better cooperation for the future of relations between the two countries. Visit Indonesian Foreign Minister Ali Al-Atas to Canberra in March 1989, has strengthened relations between the two countries (Sugiharti,1977). At least, the exchanges of high-ranking officials have been resumed after a delay due to the crisis and the East Timor crisis Sydney Morning Herald. During that time, the fact that more Australian officials who visited Indonesia in comparison with Indonesian officials who visited Australia

\section{Discussion}

\section{Enterprises Building Cooperation}

a. Australian Foreign Political policy Whitlam Era

Prime Minister Whitlam government in power since 1972, trying to adapt the Australian foreign affiliated with the international situation has changed, especially regarding diplomatic relations with Indonesia (T.B. Millar, 1978:405-406). Therefore, Whitlam visited Jakarta in February 1973, to convince Suharto about Canberra's relations with Beijing (Albinsky, 1977).

Because of its geographical location, however, Indonesia is always included in the framework of the calculation of the Australian defense strategy analyst. Unlike in the Old Order, New Order Indonesia in the past is no longer seen as a threat to Australia. Whitlam outlook is not much different from what was calculated by other Australian defense analyst (Munster \& Richard Walsh, 1982: 54; Patience \& Brian Head, 1979: 
271). ${ }^{1}$...there is no foreseeable major threat to Australia for fifteen years", says Whitlam with full confidence (Oakes, 1973: 213.

Basically Whitlam does not stand alone. A group without an institution called "The Indonesian Lobby" defended argument Whitlam. The group consisting of the Australian ambassador to Indonesia, author, and foreign ministry officials were assumed: a) Australia is more likely to have an influence on Jakarta, when Australia is seen as a friendly country and sympathetic by Jakarta; b) The destruction or collapse of the Old Order government under Sukarno in Jakarta at the time, would create political stability in Southeast Asia, more worrying for Australia (Australian Outlook, 1986: 137). ${ }^{2}$

Whitlam government also supports the concept of ASEAN on a zone of peace, freedom and neutrality in South-East Asia. Whitlam was also willing to provide assistance to train the Indonesian armed forces along with weapons engineering facilities. Australia, according to Whitlam, do not look for a binding agreement or formal alliance, but only build mutual understanding based on mutual trust and friendship. Australia, too, wants to build a new map in the relationship of its foreign policy, namely by reducing the pressure on the military pact that is no longer appropriate to the circumstances of the times (Azwar, 1997).

In the realization of its cooperative relations with Indonesia, Australia has made the biggest since June 30, 1973 totaling \$ A 53, 8 million as a form of seriousness Australia on bilateral cooperation with Indonesia. Likewise, until June 30, 1976, Australia has issued grants to Indonesia as a three-year program of \$ A 69 million. All Australian aid to

${ }^{1}$ A more complete discussion of the "Document on the Australian Defense and Foreign Policy 1968-1975, can be Seen in the George Munster and Richard Walsh, Secret of States, Sydney: Angus and Robertson Publishers, 1982, p.54.

2 The members of" the Indonesian Lobby" is centered on a former Australian Ambassador to Indonesia, G.A. Jokel, R.W. Furlonger, K.C.O. Shann, T.K. Chrichley, R.Dalrymple, R. Woollcott, and William Morrison. The senior members of the Ministry of Foreign Affairs of Australia, H.D. Holloway and G. Forrester. Academics, Heinz Arndt, Jamie Mackie and Peter McCawley. Also these are party leaders, such as Ian Sinclair and Gough Whitlam himself. See, Richard Robinson, "Explaining Indonesia's Response to the Jenkins article: "Implications for Australia-Indonesia Relations" in Australian Outlook, Vol.40, No. 3, December 1986, p. 137. 
Indonesia is in the form of grants, and there is no obligation to repay the debt partially or free or grants (Embassy of Australia, 1973:7; Mackerels, 1978: 164; Aitkin Don, 1989: 67-68).

\section{b. Involvement in Timor Problems}

Later, other important issues in this paper, is the problem of East Timor. The discussion on the question of East Timor, Whitlam did not have fundamental differences with Suharto. The integration of the region into the territory of Indonesia is seen as the most realistic option. For Whitlam, the uncertainty that occurs in the region will not just harm the interests of Indonesia or Australia, but further endanger the stability of the Southeast Asian region as a whole (Wolcott, 1975: 197-202; Toohey, 1986: 143-195.

The issue of East Timor coloring Australian foreign policy during the government of Prime Minister Whitlam (1972-1975), during the LiberalNational coalition, Fraser (1975-1983), and when the Prime Minister of Labor, Hawke power since 1983. In the matter East Timor, Whitlam, who was currently in power, held a meeting with President Suharto in Yogyakarta in September 1974.In this meeting; they discussed the problem of East Timor for the first time. In its official statement, Whitlam saw East Timor would not be a stand-alone independent state, which would threaten stability in the region (Flitzgerald, 1977: 55). Whitlam also requires that the East Timorese be given the full right to determine its own future.

This shows that Whitlam did not want any other country to take over the territory by force (Hamid, 1999: 423-424). Whitlam also said that the integration of East Timor into Indonesia is the best solution. However, Whitlam reminded, that the aspirations of East Timor must be considered and "the public reaction in Australia will be ignited if Indonesia using military force (Suryadinata, 1998: 68). According to Whitlam, the uncertainty that occurs in the territory of East Timor not only harm the interests of Indonesia or Australia, but an even greater impact and jeopardize the stability of the Southeast Asian region as a whole (Muslim, 1990: 83).

However, on December 4, 1975, the Indonesian government welcomes with joy the incorporation of the territory which is expressed in a "declaration 
of Balibo". On December 7, 1975, the entire city of Dilli, has been controlled by forces Apodeti, UDT, and Trabalista, supported by Indonesian volunteers. The presence of these volunteers Indonesia, at the request of the East Timorese through the House of Representatives of the Republic of Indonesia (DPR-RI). This, of course, difficult for the Indonesian government banned the volunteers, arguing protect the internally displaced East Timorese Fretilin of oppression and terror (Poseponegoro \& Notosusanto, 1999: 493; Suryadinata, 1998: 116).

Many reasons for Indonesia to intervene, so that the territory of East Timor integrates into Indonesia. There are two main factors that become reasons: first, the government of Indonesia-East Timor interested in long before the advent of open dispute.

Second, when Indonesia prepares independence, both Mohammad Yamin and Sukarno tried to enter the territory of East Timor into the power of the Republic of Indonesia Independent. It turns out the ideals and desires of Sukarno, had been answered when the New Order government in power under the control of Suharto, who became President of the Republic of Indonesia in 1967. At the time of this power, precisely in August 1976 of the territory formally join the Republic of Indonesia.

\section{Australian Foreign Political Policies Fraser Era}

a. Continuing political policy Whitlam

Malcolm Fraser, became Prime Minister Gough Whitlam replaced the sacked Governor-General Sir John Kerr in November 1975. The pattern of foreign policy towards Indonesia Fraser lots is affected by changes in the balance of power system in Southeast Asia, particularly the release of the United States from Vietnam continued with the US competition with the Soviet Union in the Indian Ocean region (Munster \& Richard Walsh, 1982: 55).

Fraser excessive panic, it was seen in an attempt to form a joint military pact, Australia, China, Japan, and the United States in order to stem the influence of the Soviet Union in the Asia Pacific region. Indeed pact stated in the "Doctrine of Fraser" was never implemented, but the similarity of interests between the foreign policy of Australia to the United States, and several other major countries, is sufficient evidence of concrete 
(Girling, 1977). United States also sees the importance of Indonesia as a guarantor of the stability of Southeast Asia (Muslim, 1990: 84).

However the magnitude of Fraser doubts on the ability of the noncommunist countries of the ASEAN, but Fraser cannot escape from the reality, that Australia should follow the flow of interest magnitude companions, United States. Especially in the case of Indonesia, in addition to geographical factors, the United States is very prominent factor in influencing foreign politics Fraser to Indonesia (Wolcott, 1975). Concerns Fraser against the Soviet threat Fraser further strengthen efforts to establish good relations with Indonesia.

This can be seen in what is said by Peacock in front of the parliamentary session in October 1976, that Australia, despite having some differences in principle (the problem of East Timor) must not place himself hostile to the biggest neighbor. This shows that Fraser be very careful in maintaining good relations with Jakarta. For Fraser, there should be no harm good relations between the two countries are friends, which has been built since the struggle for Indonesian independence (James \& Robert Pfaltzgraff, 1986).

b. The involvement in the issue of East Timor

However, the good relations between the two countries have been affected, after the emergence of the problem of East Timor. Indonesia who enters the territory of East Timor into its territory through military force received strong opposition from various groups in Australia. Fraser would not want to pay attention to the aspirations of the people of Australia, and takes an anti- Indonesia in the first session of the UN Security Council on the issue of East Timor, in December 1975. However in December 1976, on the occasion of his visit to Indonesia, Fraser has given recognition de Australia facto towards the integration of East Timor (Hamid, 1999: 424; Suryadinata, 1998: 117).

In the issue of the Timor Gap, for Australia under leadership Fraser needs special attention. Disputed territory between Australia and Indonesia, seemed more economical and political, which then affects the Fraser immediately recognize the integration of East Timor. On the back 
of this issue there are pressure groups of Australian petroleum industry has a direct interest in the Timor Gap (Richard H, 1992).

Companies such as Atlantic Richfield, British Petroleum, Australia Mesa, and the other holds exploration concessions in the disputed area between Australia and Indonesia, there have been encouraging Fraser to immediately adjust relations between the two countries so that exploration can be done immediately (Valencia \& Danusaputra, 1984).

Response Jakarta on this issue, of course, put the card Timor Gap to achieve de jure recognition of Australia towards the integration of East Timor. Without admitting it de jure, Fraser had simply cannot expect talks on the continental shelf boundary in the Timor Gap can be held. Indeed, the fact then, after recognition of the integration awarded in December 1978, then a new round of Timor Gap negotiations could begin (Toohey, 1995: 239-241).

Although, Australian Foreign Minister Andrew Peacock in the government of Prime Minister Fraser expressed his disappointment with the merger of the problem of East Timor into Indonesia, but the Australian Ambassador in Indonesia, "Richard Woollcott" urged Australians to accept the reality of East Timor. Finally, the Australian government recognizes de jure the incorporation of East Timor as part of Indonesia in January 1978 (Warjo, 1996).

\section{Australian Foreign Political Policy Bob Hawke Era.}

a. Build Cooperation

Immediately, after Bob Hawke was elected as the new Prime Minister of Australia, in March 1983, he laid the foundation of Australian foreign policy towards Indonesia. Hawke did not see the things that make Australia hesitate to establish good relations with countries that are very close, and have economic meaning-strategic importance (Albinsky, 1983: 156). However, the business is in fact not gone smoothly. Hawke still have to face platform Labor Party has outlined its policy on the issue of East Timor.

Labor party, the question the status of East Timor earlier in the Fraser has been legally recognized as its integration into Indonesia (Richardson, 1984). Likewise, the Australian press reports problems to 
Indonesia. In the reign of this Hawke Indonesia unexpected reaction, has resulted in worsening relations between the two countries.

Hawke, is a pragmatist and a realist. Adhering to the existing state of the environment, he still tried to create a good relationship with Indonesia. Australian foreign policy towards Indonesia, will take place in line with the global policy of the United States and Japan. Indeed, it cannot be denied, that the ASEAN countries had been enjoying the security umbrella the US, and they see the growing Soviet presence in Southeast Asia and the Pacific, could threaten the political stability and security, as compared to the PRC. Therefore, the calculation of Canberra strategy against the Soviet Union based on the relative direction of the same instructions with the strategy of the United States, Japan and other ASEAN countries (Richardson, 1984:38).

The political calculations, bringing Hawke assess a good relationship with Jakarta is a must for Canberra in its efforts to create political and economic stability in Southeast Asia. Indonesia's position in ASEAN and all its potential, making Indonesia a major regional stabilizer. As well, former Whitlam, Hawke realized that it is impossible to create stability in Southeast Asia without including Indonesia in it. Further than that, with a good relationship with Indonesia, Hawke can focus on the region began to attract attention superpower, in the South Pacific?

b. East Timor problem and response on the Sydney Morning Herald.

The emergences of the problem of East Timor in the formulation of foreign policy of Australia to Indonesia, efforts to create good relations with Jakarta, become obstructed. Negotiations concerning the delimitation of the continental shelf Timor Gap were delayed by Jakarta. This in turn again made uneasy petroleum Australian entrepreneurs in the country. They basically want clarity on the status of existing concessions to them in the region as soon as possible. Canberra's response to this question was really difficult for him, since it is unlikely that the issue be discussed and decided without Indonesia in it.

Hawke did not run what is outlined by the platform party seriously. Economic aid and defense are there still be given to Indonesia 
(Albinsky, 1983: 156). Hawke felt that it was unrealistic and even dangerous for Australia to reduce or terminate foreign aid from Australia whose number is relatively meaningless to Jakarta, can be regarded as a moral blow that may lead to serious consequences in the relations between the two countries. And of course, the result is too expensive to be paid by its national interests, both against Indonesia and the Southeast Asian region (Albinsky, 1983: 156).

Through the above considerations, Hawke tried to resolve the problem of East Timor based on the internal problems in the Australian Labor Party. This problem can only be solved in 1985, when Labor was willing to discuss the problem of East Timor at the National Conference of the Labor Party in 1984. Through the conference, Hawke managed to bring radical groups in the Labor Party to accept the integration of East Timor. After recognition of the integration of the month of August 1985, both Indonesia-Australia relations seemed to be recovering. But in reality, the opposite happens. Australian press proclaimed negative tone things towards Jakarta, especially since the death of five Australian journalists in East Timor in 1975. (Tiffens, 1978; J Jenkins, 1986). ${ }^{3}$ Therefore, a politic situation is quite difficult to be faced by Hawke, if trying to limit press freedom in his country (Hurst, 1987: 351).

The description above, has made it clear that how Hawke effort not to "bargain" on the issue of press freedom. The operation problems "values and culture" in a matter Herald does not occur between the Australian government and the Indonesian government, but more of a problem Hawke in the country. Nevertheless, many analysts see the crisis from the perspective of cultural Herald. However, when viewed carefully, it appears that none of the problems that have occurred between Canberra and Jakarta is motivated by the cultural dimension. Similarly to the case of East Timor, more coloring matter of interest to the crisis.

\footnotetext{
${ }^{3}$ Relationship become damaged due to the Sydney Morning Herald, April 10 1986, came after Indonesian Foreign Minister Mochtar Kusumaatmadja visited Australia in December 1986, which also discussed the possibility of a visit by President Soeharto to Australia. Mochtar the visit of Foreign Minister of the Republic of Indonesia first 10 years that time
} 


\section{E. Conclusion}

The government of Canberra seems to have a good relationship with the government in Jakarta. Both are in the framework of its own national interest and in the context of Australia's relationship with the United States. It can be traced in Australian foreign policy from the time of Whitlam, Fraser until Hawke, although there are differences emphases.

Whitlam, tended to start the Cabinet program by his own definition (the Labor Party) by the changes in the international situation and the formulation of the national interest of Australia, compared to the influence of US politics towards Canberra. While Fraser policies towards Indonesia is much influenced by changes in the situation of Southeast Asia, and the emergence of the Soviet Union as a power Blue Ocean Navy around Australia.

Against Indonesia, in particular the problem of East Timor, the United States has no small role for Canberra, and also very cautious in taking positions that could "hurt" Jakarta. In addition, Fraser faced political and economic situation is difficult, before it can issue a policy that is beneficial to the improvement of the Australia-Indonesia relations.

As with Fraser, Hawke even closer to the United States. The changes to the situation in Southeast Asia and the Pacific Southwest, reminiscent of the Soviet threat is getting closer. Therefore, Hawke tried to establish relations with Indonesia, which is geographically important, both politically strategic, defense, and economic. However, due to the tightness of the Labor Party to maintain its platform, Fraser was difficult to create good relations with Indonesia. In addition, the problem that occurs because of the news of the Australian press is quite troublesome Hawke in the country.

The third Prime Minister of the above, it seems no one can deny, that the proximity (geographically) between Indonesia and Australia, is a relatively permanent basis for Australian foreign policy orientation towards Indonesia. Similarly, the interests of the United States to Southeast Asia, particularly Indonesia, often play in determining the policy direction of Canberra to Jakarta. This is evident in the conditions, where Australia has a problem with Indonesia. All the Prime Ministers, from Whitlam, Fraser and Hawke showed a real effort to make adaptive Australia foreign policy towards Indonesia in its history. 


\section{Bibliography}

Achinike, H., \& Ogbonna, S. (2016). Federalism Critical Arguments as The Transfigurations of Nigerian Federalism. Jurnal Ilmiah Peuradeun, 4(3), 369-382.

Adil, H. (1977). Australia Policy towards Indonesia during Confrontation 19621966. Singapore: Institute of Southeast Asian Studies.

Albinsky, H. S. (1983). Australian Labor and Foreign Policy. Australian Outlook, 37 (3): 156.

. (1977). Australian External Policy under Labor. Brisbane: University of Queensland Press.

Beer, C. (2015). Democracy and Gender Equality. Jurnal Ilmiah Peuradeun, 3(2), 323-342.

Don, Aitkin. (1989). Australian Political Institutions (Four Edition). Melbourne: Pitman Publishing.

Dzalil, Azwar. (1997). Proyek Kerjasama Keamanan Indonesia-Australia dalam Rangka Memantapkan Stabilitas Regional. Jakarta: Lemhanas.

Dwi Rohmawan, I. (2010). Kebijakan Politik Australia: Analisis Terhadap Peranan Australia dalam Mempertahankan Kemerdekaan Republik Indonesia (1945-1949). Yogyakarta: FISE.

Fitzgeral, S. (1977). China and the World. Canberra: Australian National University Press.

Girling, J.L.S. (1977). Australia and Southeast Asia in the Global Balance: A Critique of the Fraser Doctrine, in Australian Outlook. Vol. 31. December.

Hamid, Z. (1999). Sistem Politik Australia. Bandung: LIP-FISIP-UI, PT Remaja Rosdakarya.

Haynes, J. (2015). Religion in Global Politics: Explaining Deprivatization. Jurnal Ilmiah Peuradeun, 3(2), 199-216.

Hughes, K. J., \& Batten, L. (2016). The Development of Social and Moral Responsibility in Terms of Respect for the Rights of Others. Jurnal Ilmiah Peuradeun, 4(2), 147-160.

Hurst, J. (1987). A Clash of Cultures: Indonesia and the Australian Media. The Australian Quarterly, spring and summer. 
Isri, S. (2014). Konsep Pendidikan Jerman dan Australia. Jurnal Ilmiah Peuradeun, 2(2), 261-286.

James, E. D. \& Robert, P. Jr. (1986). American Foreign Policy FDR to Reagan. New York: Harvest and Row Publisher.

Jenkins, D. (1986). After Marcos, New for Soeharto Billions. Sydney Morning Herald 10 April.

Kantor Penerangan Kedutaan Besar Australia (1973). Pidato Perdana Menteri Australia. Jakarta: Kedutaan Besar Australia.

Djonoed, M. \& Notosusanto. (1999). Sejarah Nasional Indonesia VI, Jakarta: PN Balai Pustaka.

Mackerels, M. (1978). This Australia. Sydney: Uren Smith.

Muslim, E. (1990). Politik Luar Negeri Australia Terhadap Indonesia: Dari Pemerintahan Whitlam Sampai Hawke. Journal Ilmu Politik. 39 (6): 80-81.

Musster, G. \& Walsh, R. (1982). Secret of States. Sydney: Angus and Robertson Publishers.

Millar, T.B. (1978). The Whitlam Experiment Australian in Peace and War. Canberra: Australian National University Press.

Oakes, L. (1973). Whitlam PM: A Biography. Sydney: Angus and Robertson Publishers.

Patience, A. \& Head, B. (1979). From Whitlam to Fraser. Reform and Reaction in Australian Politics. Melbourne: Oxford University Press.

Richard H. C. (1992). Budaya dan Politik Australia. Jakarta: Yayasan Obor Indonesia.

Richardson, M. (1984). The Influence in ASEAN Community of AustralianAmerican Alliance Security. Australian Outlook. 38 (3): 68

Robinson, R. (1986). Explaining Indonesias Response to Jenkins Article: Implications for Australia-Indonesia Relations. Australian Outlook. 40 (3): 137.

Sugiharti, S. (1995). Hubungan Australia-Indonesia: Faktor Geografi, Politik dan Strategi Keamanan. Jakarta: Universitas Indonesia.

Suryadinata, L. (1998). Politik Luar Negeri Dibawah Soeharto. Jakarta: LP3ES.

Tiffens, R. (1978). The New from Southeast Asia. The Sociological of News Making. Singapore: Institute of Southeast Asian Studies. 
Toohey, B. (1986). The Book of Leaks. North Ride: Angus and \& Robertson Publishers. (1995). The Timor Papers in the Book of Leaks.

Valencia, M. J \& Danusaputra, M. (1984). Indonesia: Law of the Sea and Foreign Policy Issues. Indonesian Quarterly. XII (4): 117.

Warjo. (1996). Analisis Hubungan Australia-Indonesia 1945-1992. Jakarta: Gramedia.

Watt, A. (1968). The Evaluation of Australian Foreign Policy 1938-1965. Eynesbury: Cambridge University Press.

Weinstein, B. F. (1976). Indonesian Foreign Policy and Dilemma of Defense from Soekarno to Soeharto. Ithaca: Cornell University Press.

Wolcott. (1975). Document on Australian Defense and Foreign Policy 19681975. Melbourne: Pitman Publishing. 